\title{
Antipiretik Ekstrak Etanol Daun Kemangi Aceh (Ocimi sancti folium) Pada Mencit
}

\author{
Ria Ceriana*, Nora Elsaputri, Riska Nadia, Syifa Yulia, Indah, Siti Mulyana, Elvita Meivianthy, Nisaul Fitria, \\ Nisa Ulfitria, Siti Raihan Utami \\ DIII Farmasi, Akademi Farmasi YPPM Mandiri, Banda Aceh, Indonesia \\ Email: cherry4n4@yahoo.com \\ $(*$ : coressponding author)
}

\begin{abstract}
Abstrak-Obat tradisional atau obat herbal banyak digunakan oleh masyarakat awam karena dinilai lebih aman daripada penggunaan obat modern. Hal tersebut disebabkan karena obat tradisional lebih sedikit efek samping daripada obat modern. Tujuan penelitian ini adalah untuk mengamati efek antipiretik ekstrak etanol daun kemangi pada mencit. Rancangan percobaan dalam penelitian ini menggunakan Rancangan Acak Lengkap (RAL) dimana terdapat 4 perlakuan dan 4 ulangan. Perlakuan dalam penelitian ini yaitu perlakuan control/P0 (tidak divaksin dan diberi ekstrak), P1 (mencit divaksin dan diberi 0,5 ml ekstrak daun kemangi), P2 (mencit divaksin dan diberi 0,7 ml ekstrak daun kemangi), P3 (mencit divaksin dan diberi akuades). Hasil penelitian menunjukkan suhu tubuh mencit yang sudah meningkat akibat diinjeksi vaksin DPT mengalami penurunan setelah diberi ekstrak daun kemangi. Perlakuan P2 yaitu perlakuan ekstrak sebanyak $0,7 \mathrm{ml}$ memberikan efek yang signifikan pada penurunan suhu tubuh mencit.
\end{abstract}

Kata Kunci: Antipiretik; Ekstrak; Ocimi Sancti Folium; Kemangi; Etanol

\begin{abstract}
Traditional medicine or herbal medicine is widely used by ordinary people because it is considered safer than the use of modern medicine. This is because traditional medicine has fewer side effects than modern medicine. The purpose of this study was to observe the antipyretic effect of the ethanolic extract of basil leaves on mice. The experimental design in this study used a completely randomized design (CRD) where there were 4 treatments and 4 replications. The treatments in this study were control/P0 (not vaccinated and given extract), P1 (mouse vaccinated and given $0.5 \mathrm{ml}$ of basil leaf extract), P2 (mouse vaccinated and given $0.7 \mathrm{ml}$ of basil leaf extract), P3 (mouse vaccinated and given aquadest). The results showed that the body temperature of the mice that had increased due to the DPT vaccine had decreased after being given basil leaf extract. The P2 treatment, namely the extract treatment as much as $0.7 \mathrm{ml}$ gave a significant effect on reducing the body temperature of mice.
\end{abstract}

Keywords: Antipyretic; Extract; Ocimi Sancti Folium; Basil; Ethanol

\section{PENDAHULUAN}

Indonesia merupakan Negara kepulauan yang luas sekitar 9 juta km2 yang terletak diantara dua samudra dan dua benua. Kondisi geografis tersebut membuat Indonesia menjadi Negara mega biodiversitas dimana memiliki kekayaan sumber daya alam yang beraneka ragam (Kusmana dan Hikmat, 2015). Keanekaragaman hayati merupakan variasi atau perbedaan bentuk-bentuk makhluk hidup, meliputi perbedaan pada tumbuhan, hewan, mikroorganisme, materi genetik, serta bentuk ekosistem tempat hidup suatu makhluk hidup. Keanekaragaman hayati juga disebut Biodiversitas. Keanekaragaman atau keberagaman dari makhluk hidup dapat terjadi karena akibat adanya perbedaan warna, ukuran, benuk, jumlah, tekstur, penampilan dan sifat-sifat lainnya (Ridhwan, 2012). Indonesia memiliki flora dimana 25\% dari spesies tumbuhan berbunga dan $40 \%$ tumbuhan endemik atau asli Indonesia (Kusmana dan Hikmat, 2015). Berbagai jenis tumbuhan tersebut banyak digunakan sebagai obat tradisional.

Obat tradisional atau obat herbal banyak digunakan oleh masyarakat awam karena dinilai lebih aman daripada penggunaan obat modern. Hal tersebut disebabkan karena obat tradisional lebih sedikit efek samping daripada obat modern (Sumayyah dan Salsabila, 2017). Obat tradisional atau obat herbal dapat digunakan pada pelayanan kesehatan formal apabila melalui pembuktian khasiat dan keamanan obat melalui uji klinik. Penelitian dan pengembangan obat tradisional menjadi fitofarmaka cukup baik, akan tetapi sering terbentur pada masalah dana penelitian yang sulit didapat (Dewoto, 2007). Ketepatan penggunaan obat tradisional untuk meminimalisir efek sampingnya seperti kebenaran obat, ketepatan dosis, ketepatan pemilihan waktu penggunaan, ketepatan cara penggunaan, tidak disalahgunakan dan ketepatan pemilihan obat untuk penyakit tertentu (Sumayyah dan Salsabila, 2017). Oleh karena itu penelitian ini penting dilakukan untuk menguji secara ilmiah kebenaran salah satu tumbuhan yang digunakan dalam obat tradisional yakni daun kemangi.

Daun Kemangi memiliki khasiat antimikroorganisme seperti Candida albicans (De Ornay et al., 2017), dan bakteri Staphylococcus aureus (Ariani et al., 2020). Ekstrak daun kemangi banyak diaplikasikan ke dalam bentuk sediaan seperti hand sanitizer dimana dapat membunuh Staphylococcus aureus dan E.Coli (Cahyani, 2014), penyegar mulut (Harmely et al., 2014), gel antijerawat (Kindangen, 2018). Karena memiliki khasiat antimiroorganisme maka dibuat dalam sediaan salep dan minyak atsiri. Salep ekstrak daun kemangi dapat memberikan efek penyembuhan infeksi yang lebih cepat (Naibaho et al., 2013) sedangkan minyak atsiri daun kemangi memiliki aktivitas antiinflamasi (Saputri dan Zahara, 2016) karena juga dapat menghambat pertumbuhan jamur (Martiningsih, 2017). Ekstrak daun kemangi dilaporkan oleh Aldi et al., (2016) memiliki efek imunostimulan yang ditunjukkan adanya peningkatan total leukosit. Semua khasiat daun kemangi tersebut dikarenakan daun kemangi mengandung berbagai senyawa metabolit sekunder yang bermanfaat bagi manusia. Daun kemangi menurut penelitian Widiastuti (2016) pada tikus putih menunjukkan bahwa daun kemangi memiliki efek antipiretik. Akan tetapi belum ada laporan penelitian daun kemangi yang berasal dari Aceh dan dlakukan 
Journal of Pharmaceutical and Health Research

Vol 3, No 1, Februari 2022, pp. 15-18

ISSN 2721-0715 (media online)

DOI 10.47065/jharma.v3i1.1311

pengujian pada mencit. Tujuan penelitian ini adalah untuk mengamati efek antipiretik ekstrak etanol daun kemangi pada mencit.

\section{METODOLOGI PENELITIAN}

\subsection{Jenis Penelitian}

Penelitian ini menggunakan metode eksperimental laboratorium dimana menggunakan hewan coba sebagai objek penelitian.

\subsection{Tempat dan Waktu Penelitian}

Penelitian ini dilaksanakan di Laboratorium Farmkologi Akademi Farmasi YPPM Mandiri Banda Aceh. Penelitian ini dilaksanakan pada tanggal bulan November 2021 sampai Januari 2022.

\subsection{Alat dan Bahan Penelitian}

1. Alat - alat

Alat - alat yang digunakan pada penelitian ini adalah gelas beker, timbangan digital, masker, sarung tangan, spuit, alat sonde pencekok / oral $1 \mathrm{ml}$, thermometer, stopwatch dan kapas / tisu steril.

2. Bahan - bahan

Bahan-bahan yang dgunakan pada penelitian ini adalah ekstrak daun kemangi, vaksin DPT, etanol 96\%, aquadest.

\subsection{Rancangan Percobaan}

Rancangan percobaan dalam penelitian ini menggunakan Rancangan Acak Lengkap (RAL) dimana terdapat 4 perlakuan dan 4 ulangan. Perlakuan dalam penelitian ini yaitu perlakuan control/P0 (tidak divaksin dan diberi ekstrak), P1 (mencit divaksin dan diberi $0,5 \mathrm{ml}$ ekstrak daun kemangi), P2 (mencit divaksin dan diberi 0,7 ml ekstrak daun kemangi), P3 (mencit divaksin dan diberi akuades).

\subsection{Prosedur Kerja}

1. Identifikasi Sampel

Identifikasi bahan dilakukan di Laboratorium Biologi Akademi Farmasi Yppm Mandiri Banda Aceh .

2. Pembuatan Simplisia Daun Kemangi

Daun kemangi dibersihkan dengan air mengalir, lalu daun kemangi dipisahkan dari batangnya. Daun kemangi ditimbang sebanyak $1 \mathrm{~kg}$ lalu dipotong-potong kecil. Daun kemangi kemudian dikeringkan dengan suhu ruangan sampai daun kemanginya benar-benar kering sehingga mudah disimplisiakan. Lalu daun kemangi yang sudah kering disimplisiakan dengan cara diremas-remes sampai daun kemangi hancur, kemudian ditimbang daun kemangi sebagai berat kering. Simplisia yang sudah jadi di simpan dalam wadah yang terlindungi dari sinar matahari (Febria, 2012).

3. Pembuatan Ekstrak Daun Kemangi

Pembuatan ekstrak etanol daun kemangi dilakukan dengan cara maserasi yaitu sebanyak 200 g serbuk simplisia dimasukkan kedalam wadah, kemudian direndam dengan larutan etanol $70 \%$ sebanyak $1000 \mathrm{~mL}$ selanjutnya ditutup dengan penutup wadah selama 24 jam sambil sesekali diaduk. Sampel yang telah direndam tersebut disaring menggunakan kertas saring dan menghasilkan filtrat 1 dan residu 1. Residu yang ada selanjutnya ditambahkan dengan larutan etanol 70\% sebanyak $1000 \mathrm{~mL}$, kemudian ditutup dengan wadah penutup dan dibiarkan selama 24 jam sambil sesekali diaduk. Setelah penyimpanan 24 jam, dilakukan penyaringan dengan menggunakan kertas saring. Hasil dari penyaringan kedua ini menghasilkan filtrat 2 dan residu 2. Kemudian filtrat 1 dan 2 dicampurkan menjadi satu dan diuapkan menggunakan Rotary vacuum evaporator. Hasil yang diperoleh selanjutnya dipekatkan di atas waterbath pada suhu $40^{\circ} \mathrm{C}$ hingga diperoleh ekstrak kental. Ekstrak disimpan dalam suhu dingin $5-10^{\circ} \mathrm{C}$ yang selanjutnya akan digunakan pada Penelitian uji efektiviitas daun kemangi pada mencit (Djumaati et al., 2018).

4. Aklimatisasi Hewan Coba

Hewan coba yang digunakan dalam penelitian ini ialah mencit. Mencit diadaptasikan sesuai lingkungan laboratorium selama 1 minggu. Mencit diletakkan di dalam kandang berukuran 50 x $45 \mathrm{~cm}$ yang diberi alas sekam padi dan ditutupi kawat jaring. Mencit diberi makan dan minum secara ad libitum.

5. Perlakuan Hewan Coba

Mencit perlakuan P1, P2 dan P3 terlebih dahulu diinjeksikan vaksin DPT sebanyak 0,1 ml agar suhu tubuh mencit meningkat dan demam. Setelah 1 jam injeksi, suhu tubuh mencit diukur menggunakan thermometer. Apabila suhu tubuh mencit sudah meningkat, maka mencit diberi ekstrak daun kemangi secara oral kecuali mencit perlakuan kontrol (P0) dan P3 yang hanya diberi akuades. Setelah 30 menit pemberian ekstrak, maka suhu tubuh mencit diukur kembali untuk mengamati efek antipiretik.

\subsection{Analisis Data}

Data yang telah didapatkan dari hasil pengamatan tersebut dicatat dan sajikan dalam bentuk tabel. Data dihitung menggunakan hasil rata-rata dari setiap perlakuan dan ulangan. Selanjutnya data dibahas secara deskriptif. 
Journal of Pharmaceutical and Health Research

Vol 3, No 1, Februari 2022, pp. 15-18

ISSN 2721-0715 (media online)

DOI 10.47065/jharma.v3i1.1311

\section{HASIL DAN PEMBAHASAN}

\subsection{Hasil}

Hasil pengamatan suhu tubuh mencit yang telah diukur menggunakan termometer disajikan ke dalam tabel di bawah ini. Tabel 1. Rat-rata hasil pengamatan suhu tubuh mencit (hasil akhir) setelah pemberian Vaksin DPT dan ekstrak Daun kemangi selama selang waktu 30 menit :

Tabel 1. Rat-rata hasil pengamatan suhu tubuh mencit

\begin{tabular}{llccc}
\hline No. & Perlakuan & Rata-rata Suhu Awal & Rata-rata suhu injeksi vaksin & Rata-rata suhu setelah pemberian ekstrak \\
\hline 1. & P0 (kontrol) & $35^{\circ} \mathrm{C}$ & $38,4^{\circ} \mathrm{C}$ & $38^{\circ} \mathrm{C}$ \\
2. & P1 & $34,9^{\circ} \mathrm{C}$ & $39^{\circ} \mathrm{C}$ & $37,5^{\circ} \mathrm{C}$ \\
3. & P2 & $36^{\circ} \mathrm{C}$ & $38,6^{\circ} \mathrm{C}$ & $37^{\circ} \mathrm{C}$ \\
4. & P3 & $35^{\circ} \mathrm{C}$ & $38^{\circ} \mathrm{C}$ & $37,9^{\circ} \mathrm{C}$ \\
\hline
\end{tabular}

Tabel 1 menunjukkan bahwa perlakuan kontrol tidak mengalami penurunan suhu yang signifikan. Perlakuan P1, P2 dan P3 mengalami kenaikan suhu tubuh setelah diberi vaksin DPT. Vaksin DPT dapat menimbulkan gejala demam karena reaksi tubuh mencit. Akan tetapi suhu tubuh mencit mengalami penurunan setelah diberi ekstrak daun kemangi. Hal tersebut dapat dilihat pada perlakuan P1 dan P2 dimana suhu tubuh mencit turun mencapai $37^{\circ} \mathrm{C}$. Sedangkan perlakuan P3 tidak mengalami penurunan suhu tubuh karena hanya diberi akuades.

\subsection{Pembahasan}

Ekstrak daun kemangi terbukti memiliki efek antipiretik. Hal tersebut ditunjukkan dari hasil pengamatan suhu tubuh mencit yang sudah diberi vaksin mengalami penurunan suhu tubuh. Berdasarkan penelitian Angelina et al., (2015), ekstrak etanol daun kemangi mengandung flavonoid, tannin dan minyak esensial dimana senyawa tersebut memiliki sifat antibakteri. Kumalasari dan Andiarna (2020) juga menambahkan bahwa di dalam ekstrak etanol daun kemangi terdapat senyawa alkaloid dan saponin selain flavonoid dan tannin. Berbagai kandungan tersebut dapat membantu menurunkan demam pada mencit. Demam menurut Guyton (1990) bahwa tubuh terjangkit penyakit tertentu. Oleh karena itu, demam merupakan alat pemberitahu adanya suatu penyakit dalam tubuh. Demam yaitu suhu tubuh diatas batas normal biasa, dapat disebabkan kelainan dalam otak atau oleh zat toksik yang mempengaruhi pusat pengaturan suhu, bakteri, virus, tumor otak, atau dehidrasi.

Salah satu jenis deman yaitu deman tifoid yang disebabkan oleh bakteri. Bakteri yang sangat umum yaitu Salmonela thypii (Rahmasari dan Lestari, 2018). Kandungan dalam ekstrak daun kemangi dapat berefek imunostimulan yang dapat meningkatkan indeks fagositosis, total leukosit, sel neutrophil, eosinophil dan limfosit yang ditunjukkan dengan pertambahan berat organ limpa pada mencit (Aldi et al., 2016). Efek tersebut dapat membantu menurunkan suhu tubuh mencit karena infeksi yang terjadi di dalam tubuh mencit berkurang akibat efek imunostimulan tersebut.

\section{KESIMPULAN}

Ekstrak etanol daun kemangi yang terdapat di daerah Aceh dapat menurunkan suhu tubuh pada mencit. Hal tersebut dilihat dari penurunan suhu tubuh mencit yang demam setelah diberi ekstrak daun kemangi sebanyak 0,7 ml. Jadi, ekstrak etanol daun kemangi memiliki efek antipiretik pada mencit.

\section{DAFTAR PUSTAKA}

Aldi, Y., Dewi, O. N., \& Uthia, R. (2016). Uji imunomodulator dan Jumlah sel leukosit dari ekstrak daun kemangi (Ocimum basilicum L.) pada mencit putih jantan. SCIENTIA: Jurnal Farmasi dan Kesehatan, 6(2), 139-147.

Angelina, M., Turnip, M., \& Khotimah, S. (2015). Uji aktivitas antibakteri ekstrak etanol daun kemangi (Ocimum sanctum L.) terhadap pertumbuhan bakteri Escherichia coli dan Staphylococcus aureus. Jurnal Protobiont, 4(1).

Ariani, N., Febrianti, D. R., \& Niah, R. (2020). Uji Aktivitas Ekstrak Etanolik Daun Kemangi (Ocimum sanctum L.) terhadap Staphylococcus aureus secara In Vitr. Jurnal Pharmascience, 7(1), 107-115.

Cahyani, N. M. E. (2014). Daun kemangi (ocinum cannum) sebagai alternatif pembuatan handsanitizier. KEMAS: Jurnal Kesehatan Masyarakat, 9(2), 136-142.

De Ornay, A. K., Prehananto, H., \& Dewi, A. S. S. (2017). Daya hambat pertumbuhan Candida albicans dan daya bunuh Candida albicans ekstrak daun kemangi (Ocimum sanctum L.). Jurnal Wiyata: Penelitian Sains dan Kesehatan, 4(1), 78-83.

Dewoto, H. R. (2007). Pengembangan obat tradisional Indonesia menjadi fitofarmaka. Majalah Kedokteran Indonesia, 57(7), 205-211

Harmely, F., Deviarny, C., \& Yenni, W. S. (2014). Formulasi dan evaluasi sediaan edible film dari ekstrak daun kemangi (Ocimum americanum L.) sebagai penyegar mulut. Jurnal Sains Farmasi \& Klinis, 1(1), 38-47.

Kindangen, O. C. (2018). Formulasi gel antijerawat ekstrak etanol daun kemangi (Ocimum basilicum L.) dan uji aktivitasnya terhadap bakteri Staphylococcus aureus secara in vitro. PHARMACON, 7(3).

Kumalasari, M. L. F., \& Andiarna, F. (2020). Uji fitokimia ekstrak etanol daun kemangi (Ocimum basilicum L). Indonesian Journal for Health Sciences, 4(1), 39-44.

Kusmana, C., \& Hikmat, A. (2015). Keanekaragaman hayati flora di Indonesia. Jurnal Pengelolaan Sumberdaya Alam dan Lingkungan (Journal of Natural Resources and Environmental Management), 5(2), 187-187. 


\section{Journal of Pharmaceutical and Health Research}

Vol 3, No 1, Februari 2022, pp. 15-18

ISSN 2721-0715 (media online)

DOI 10.47065/jharma.v3i1.1311

Martiningsih, N. W., \& IAP, S. (2017). Skrining Fitokimia dan Aktivitas Antijamur Minyak Atsiri Daun Kemangi (Ocimum sp.). In Seminar Nasional Riset Inovatif (Vol. 2, No. 1, pp. 631-636).

Naibaho, O. H., Yamlean, P. V., \& Wiyono, W. (2013). Pengaruh basis salep terhadap formulasi sediaan salep ekstrak daun kemangi (Ocimum sanctum L.) pada kulit punggung kelinci yang dibuat infeksi Staphylococcus aureus. Pharmacon, 2(2).

Rahmasari, V., \& Lestari, K. (2018). REVIEW ARTIKEL: Manajemen Terapi Demam Tifoid: Kajian Terapi Farmakologis dan Non Farmakologis. Farmaka, 16(1), 184-195.

Ridhwan, M. (2012). Tingkat Keanekaragaman Hayati dan Pemanfaatannya di Indonesia. Jurnal Biology Education, 1(1).

Saputri, F. C., \& Zahara, R. (2016). Uji Aktivitas Anti-Inflamasi Minyak Atsiri Daun Kemangi (Ocimum americanum L.) pada Tikus Putih Jantan yang Diinduksi Karagenan. Pharmaceutical Sciences \& Research, 3(3), 1.

Sumayyah, S., \& Salsabila, N. (2017). Obat tradisional: antara khasiat dan efek sampingnya. Majalah Farmasetika, 2(5), 1-4.

Widiastuti, A. (2006). Efek antipiretik ekstrak daun kemangi (Ocimi sancti folium) pada tikus putih. 